\title{
Diversidad cultural y lingüística en Argelia
}

\author{
Nacer WABEAU \\ Universidad de Costa Rica
}

\begin{abstract}
La preocupación central del presente trabajo es la búsqueda de la reconciliación y del diálogo entre las culturas. Se empieza con algunas definiciones del concepto cultura para esclarecer que el tema se aborda desde una perspectiva humanística universal. Luego, se hace un breve recorrido histórico para dilucidar los orígenes de la pluralidad lingüística en Argelia. La diversidad cultural es enriquecedora; pese a las aparentes y obvias dificultades de la coexistencia con el "Otro". Los problemas actuales de Argelia no deben ser vistos desde la óptica religiosa, sino política. Las ideologías radicales son reales, mas no se debe ocultar a los poetas, escritores e intelectuales que resisten pacíficamente, con dignidad y en todas las lenguas. Se argumenta que el choque de civilizaciones es evitable y que la convivencia pacífica es posible.
\end{abstract}

PALABRAS CLAVE: cultura, Argelia, beréber, francofonía, diversidad, tolerancia, identidad, resistencia.

The main concern of this study is to search for cultural reconciliation and dialogue. It begins with definitions of the concept of culture in order to clarify that the topic is grounded in a universal humanistic perspective. The essay gives a brief historical view of the origins of linguistic plurality in Algiers. Cultural diversity is enriching, in spite of the apparent and obvious difficulties of coexistence with the so-called "Other". The actual problems in Algiers should not be considered from a religious perspective but as political issues. Radical ideologies are real, but there is no reason to ignore poets, writers and intellectuals who are resisting peacefully, in a dignified manner and from various linguistic backgrounds. The essay argues that the clash of civilizations is avoidable and peaceful coexistence is possible.

KEY WORDS: culture, Algiers, berber, francophone, diversity, tolerante, identity, resistance. 
Una cultura aislada está destinada a desaparecer... Sólo las culturas que se encuentran son culturas vivas.

Carlos Fuentes, 1991: 104

La culture vit de vérité. Mouloud Mammeri, 1987: 54

Nuestra percepción de las culturas ajenas no suele fundarse en una realidad objetiva sino en la imagen mental que tenemos de ellas.

Juan Goytisolo, 1997: 9

\section{Consideraciones preliminares y planteamiento del problema}

En el marco de "Rostros de la Francofonía 2009” en México es importante compartir algunas ideas, quizás, simples impresiones, sobre la "Diversidad cultural y lingüística en Argelia". Es un tema tan polémico que provoca tensiones y opiniones casi irreconciliables entre los argelinos. ¿Cuál es el problema? Es de conocimiento público que Argelia estuvo al borde de la desintegración en los años noventas por causa del terrorismo. Para algunos, Argelia es un país árabe-islámico y punto. Pero al menos, un tercio de su población no se reconoce en la identidad oficial y se niega a dejar de ser beréber. Se han formado movimientos que reivindican la autonomía cultural y lingüística. Argelia es el segundo país francófono más grande después de Francia, pero no forma parte, hasta la fecha, la Organización Internacional de la Francofonía (OIF). Así las cosas, resulta difícil y riesgoso abordar un tema tan problemático, sin provocar ciertas discrepancias, aunque la intención es incitar al estudio y a la reflexión con el fin de contribuir a la comprensión de la compleja situación de la diversidad cultural.

\section{Definición del concepto Cultura}

Para evitar cualquier malentendido, es preciso esclarecer nuestra perspectiva, mediante la definición del concepto Cultura. Veamos una de las definiciones que se han dado de tan complejo término, la de Sigmund Freud: "Aceptamos como culturales todas las actividades y los bienes útiles para el hombre: a poner la tierra a su servicio, a protegerlo contra la fuerza de los elementos [...] Evidentemente, la belleza, el orden y la limpieza ocupan una posición particular entre las exigencias culturales" (1970: 37).

Luego Freud señala el origen mítico de la cultura: “de tal manera, Eros y Ananké se convirtieron en los padres de la cultura humana, cuyo primer resultado fue el de facilitar la vida en común a mayor número de seres" (1970: 43). En otras palabras: el impulso de Eros-Amor y de Ananké-Necesidad son la fuente de la cultura, cuyo fin debería ser facilitar la coexistencia entre las personas que se necesitan unas a otras. 
Varios pensadores siguen este orden de ideas y coinciden en tres categorías de cultura:

Primero: el ideal de los valores universales en los cuales la cultura es la búsqueda del bienestar y de la perfección humana.

Segundo: cultura es todo lo que hace el ser humano; se puede platicar de la cultura culinaria, de la cultura de paz, pero se habla más de la cultura de la violencia, sobre todo en algunos medios de comunicación masiva. Para el tema en estudio, cultura es el conjunto de las producciones intelectuales y científicas, de las creaciones artísticas, registradas para enriquecer la experiencia humana, con el objetivo de crear condiciones que posibiliten la calidad de la vida y la búsqueda de la felicidad.

Tercero: la definición sociológica, que consiste en la descripción de los modos de vida, el arte de vivir juntos, mediante convenciones que regulan la conducta humana, con el fin de lograr la tranquilidad de todos; un conjunto de creencias, de valores, símbolos y significaciones que se transmiten de una generación a otra (Byram, 1997: 111-115).

Existe un vínculo estrecho entre los conceptos de Cultura y de Lengua, ya que las lenguas son transmisoras de las diferentes manifestaciones culturales. Además, las lenguas son parte constituyente de las culturas. Cada lengua es una riqueza humana invaluable.

La Declaración Universal sobre la Diversidad Cultural de la UNESCO indica: "La cultura debe ser considerada como el conjunto de rasgos distintivos espirituales y materiales, intelectuales y afectivos que caracterizan a una sociedad o un grupo social y que abarca, además de las artes y las letras, los modos de vida, las maneras de vivir juntos, los sistemas de valores, las tradiciones y las creencias" (2001).

En su Plan de acción, la UNESCO recomienda: "Salvaguardar el patrimonio lingüístico de la humanidad y apoyar la expresión, la creación y difusión en el mayor número posible de lenguas" (2001).

A la luz de las definiciones anteriores, podemos aseverar que no hay cultura superior y cultura inferior, toda cultura es un bien colectivo de una comunidad en particular y de la humanidad en general. Es desde esta perspectiva humanística universal que abordamos el tema de la "Diversidad cultural y lingüística en Argelia".

\section{Argelia y México: sus bellezas y contrastes mágicos}

Desde el exilio, el cantante popular Slimane Azem (1980) dice:
Algérie, mon beau pays,
Argelia mi hermoso país,
Je t'aimerai jusqu'à ma mort $[\ldots]$
Te amaré hasta la muerte.
Jamais je ne t'oublierai,
Nunca te olvidaré,
Quelque soit mon triste sort.
Sea cual sea mi triste suerte.*
* Todas las traducciones marcadas con asterisco son nuestras. 
En efecto, Argelia es un país bello, vasto y rico, habitado por un pueblo caracterizado por la generosidad y la hospitalidad. Su territorio, de 2,381,000 $\mathrm{km}^{2}(408,000$ $\mathrm{km}^{2}$ más que México), al igual que México, tiene paisajes variados y muy hermosos, con contrastes de una rara belleza y magia entre el sur y el norte. Al sur está el desierto del Sahara, donde se ubica el museo a cielo abierto más grande del mundo llamado Tassili, y al norte están las montañas verdes o cubiertas de nieve de Djurdjura, y mil doscientos kilómetros de la costa mediterránea, este mar mítico que fascinó a los griegos y a tantos otros pueblos, Mar nuestro, pero también del otro. Al igual que México, Argelia tiene una historia remota y rica en enseñanzas para las generaciones futuras. Las pirámides del Tajín y otras ciudades olmecas, toltecas y aztecas dan testimonios de las grandes civilizaciones del pasado, cuyos mensajes no hemos sabido apreciar. Por allá, en Argelia también hay ciudades y ruinas, como Djamila y Tipaza, declaradas patrimonio de la humanidad por la UNESCO.

A lo largo de un viaje de la ciudad de México hasta Morelia, los paisajes de Michoacán me parecían tan familiares que me sentía en Argelia: la vegetación, el suelo, la tranquilidad de la vida aldeana, todo me recordaba mi tierra natal, sólo que en México el nopal se disfruta en platos sabrosos como sólo los mexicanos de buena cuchara saben hacer, en Argelia con el nopal se alimenta las vacas. ¡Qué desperdicio con un alimento tan rico en fibra y bueno contra el colesterol! Por poco que un viajero, que no es lo mismo que un turista, recorra el territorio mexicano y observe a su admirable pueblo en sus quehaceres diarios, la diversidad cultural y lingüística salta a la vista. Y lo mismo se puede constatar en Argelia.

En efecto, los argelinos hablan tres lenguas: el árabe, el francés y el beréber con sus variantes. ¿Cuáles son sus orígenes? ¿Cuál es el origen de esta diversidad cultural y lingüística? La situación actual de un pueblo no se puede entender sin un breve recorrido por su proceso histórico.

\section{Breve preámbulo histórico}

Los primeros habitantes de África del Norte, de los que existen vestigios de hace más de tres mil años, son los beréberes (Ouerdane, 1990: 31). Los romanos los llamaban así; "berebere" viene de "bárbaro", es decir, ajeno a nuestra cultura. Los beréberes se designan a sí mismos "imazighen", en plural, y "amazighe", en singular. A partir de ahora, utilizaremos la palabra "amazighe" en lugar de "berebere". Amazighe significa hombre libre. Extraño destino el de los hombres libres, colonizados por siete invasores. Al igual que a México, a Argelia le invadieron a lo largo de la historia. Mouloud Mammeri indica el orden cronológico de los colonizadores de Argelia: los fenicios, los romanos, los vándalos, los bizantinos, los árabes, los turcos y los franceses (1983). Algunos de estos invasores ocuparon el país durante más de un siglo. Omar Ouerdane indica con precisión la duración de las ocupaciones parciales de algunas regiones del África del Norte: "Fenicia: 7 siglos; romana: 6 siglos; árabe: 13 siglos; otomana: 3.1/2 
siglos; portuguesa: 3 siglos; española: 2 siglos; francesa: 132 años; sin contar los pasajes de los Bizantinos y particularmente de los Vándalos" (1990: 32).*

Por otro lado, el historiador Charles André Julien observa: "Tan lejos que uno remonta en la historia del África del Norte, uno constata que todo ocurre como si estuviera golpeado por una ineptitud congénita a la independencia. Este país ha sido constantemente sometido a la influencia y a veces al destino de las civilizaciones ajenas" (1994: 57).*

Si bien el pueblo amazighe ha estado siempre en contacto con otras civilizaciones, no significa que no ha tenido periodos de monarquías autónomas. Los más destacados fueron los reinados de Masinissa y Jugurtha (Julien, 1994: 136-142). El hecho de haber sufrido tantas invasiones y de seguir en pie, con sus especificidades culturales y manteniendo su diferencia, evidencia su alta capacidad de resistencia. El historiador Ibn Jaldún destaca: "Creemos haber citado una serie de hechos que demuestran que los beréberes han sido siempre un pueblo poderoso, temible, valiente y numeroso; un verdadero pueblo como otros han existido en este mundo, árabes, persas, griegos y romanos" (Lacoste, 1985: 180).

Las civilizaciones que pasaron por África del Norte dejaron huellas: las arquitecturas de las ciudades dan testimonio, los libros de historia hablan de ello, las ruinas romanas revividas por Albert Camus: "Rocas que el mar lame con un ruido de besos [...] Amor que no tenía la debilidad de reivindicar para mí solo, consciente y orgulloso de compartirlo con toda una raza, nacida del sol y del mar, vivaz y sabrosa, que saca su grandeza de su simplicidad y, erguido sobre las playas, dirige su sonrisa cómplice a la sonrisa explosiva de sus cielos" (1984b: 55-60).*

Además, los conquistadores dejaron su sangre y sus genes. He aquí el origen del aspecto plural de los pueblos magrebinos. En efecto, algunos son morenos, otros tienen un tinte oscuro, como sus hermanos del África negra, y muchos tienen los ojos azules, cabello castaño claro o rubio, como los romanos. Hay incluso hombres azules o Tuareg (Estefanía, 2005); un pueblo admirable y valientemente enraizado en su desierto.

¿Por qué tantos invasores? Porque Argelia siempre ha sido un país de grandes riquezas. Actualmente sus reservas superan los cincuenta y cinco mil millones de dólares (Cembrero, 2005). Si hoy es conocido por sus importantes reservas de petróleo y de gas natural, cabe recordar que durante siglos fue considerado como "el granero de Roma" (Julien, 1994: 179), por sus importantes cultivos de trigo duro. Y las culturas culinarias de los pueblos mediterráneos necesitan el trigo como Mesoamérica necesita el maíz. Hoy día, Argelia es, quizás, el único país en vías de desarrollo sin un dólar de deuda externa.

El pueblo amazighe profesaba tres religiones. Uno de los pensadores más conocidos de la cristiandad es san Agustín (Marrou, 1965), de madre amazighe y devota cristiana, santa Mónica, y de padre pagano, Patricius (Julien, 1994: 265). Nacido en Tagaste, enterrado en Nipona para los romanos, Bonne para los franceses, Annaba para los argelinos. Éste es el ejemplo más evidente del cruce de culturas.

El árabe viene de la península arábiga en el Medio Oriente. La invasión de África del Norte por los árabes comenzó en el año 647 d. C., cuando la reina del pueblo Amazighe era la Kahina de confesión judía (Yacine, 1992). Ella resistió a la conquista 
árabe durante catorce años. Hasta que los soldados de Okba Ben Nafaa la asesinaron cerca del pozo que lleva su nombre: "Bir el Kahina" (Julien, 1994: 354).

El proceso de islamización de África del Norte culminó con la conquista de España, que conserva los testimonios de la grandeza de la civilización árabe-islámica, tales como la Mezquita de Córdoba, la Alhambra o la ciudad de Toledo, donde hay evidencias de que las tres religiones convivieron en el respeto mutuo, la armonía y la tolerancia. Dice Carlos Fuentes: "En 711, exactamente un siglo después de que el profeta hubiera comenzado a propagar su fe, el Islam llegó a las riberas del sur de Europa, invadiendo la España goda [...] un ejército de 7000 a 17000 beréberes del África del norte [...] El ejército de Tarik zarpó de Marruecos y desembarcó en Gibraltar, Geb-El-Tarik, llamado así en honor del invasor Beréber" (1992: 55-56).

Tarik Ben Ziyad quemó los barcos para evitar la marcha atrás. Hernán Cortés utilizó la misma estrategia en 1519, dijo: "Pero ya no hay naves, las he barrenado, ya no hay marcha atrás" (Fuentes, 1992: 121).

Generalmente las invasiones se caracterizan por la destrucción, pero también por el surgimiento de nuevas culturas. Más allá de las diferencias, el intercambio cultural entre ambas orillas del Mediterráneo es digno de ser estudiado. Resulta significativo destacar que el escritor más grande del castellano, Cervantes, estuvo encarcelado en Argel de 1575 hasta 1580 (García, 2005: 140-143) y que su famosa obra, Don Quijote de la Mancha, fuera un manuscrito de un tal historiador árabe Cide Hamete Benengeli (Cervantes, 2000: 72).

Hasta aquí, los orígenes de las lenguas árabe y amazighe están esclarecidos. Falta la tercera lengua de los argelinos: el francés, que llegó a Argelia "con las armas y las leyes", para parafrasear a Andrés Bello (1945: 25), es decir, con el desembarco del ejército francés en 1830 (Julien, 1994). México también sufrió una breve invasión francesa en 1862, pero Benito Juárez le puso un "hasta aquí no más", cinco años después. Argelia tuvo que soportarlos ciento treinta y dos años; hasta que la revolución argelina de 1954 a 1962 culminó con la independencia. Los franceses se marcharon de Argelia, la lengua francesa se quedó.

\section{El lugar del francés en Argelia}

Las palabras del dramaturgo y poeta Kateb Yacine ilustran mejor que cualquier discurso el lugar del francés en Argelia:

La lengua francesa, por su lado, ha entrado en las costumbres desde hace más de un siglo. Es una lengua transmisora, que nos pone en contacto con el mundo moderno. El árabe y el francés son medios de expresión que han permitido al pueblo argelino, hablando la lengua de los invasores, rechazar sus tentativas de integración o de asimilación, entrando, al mismo tiempo, en contacto con los pueblos de Oriente y de Occidente, portadores de una cultura de esencia universal (Maougal, 2004: 93).* 
Pese a la historia tumultuosa, Kateb Yacine destaca el aporte de la lengua francesa a la cultura argelina y recomienda con sabiduría no soltarla, en sus palabras: la lengua francesa es nuestro "botín de guerra" (Cubertafond, 1999: 119). En efecto, la lengua de Molière es también la de escritores prestigiosos, tales como Marguerite Taos y su hermano Jean Amrouche, de confesión cristiana; Mohamed Dib, Mouloud Feraoun y Tahar Djaout, y Assia Djebar, una de las pocas mujeres miembro de la Academia Francesa. En África podemos decir orgullosamente que es la lengua de Léopold Sédar Senghor, uno los fundadores de la OIF (bajo otra apelación inicialmente) y padre de la democracia en Senegal.

¿Cuál es la situación de la lengua francesa antes y después de la independencia? Aunque parezca paradójico se habla mejor después de la independencia. ¿Por qué? Porque durante la colonización hubo pocas escuelas. Lejos del discurso de "civilizar a los bárbaros africanos", los colonizadores europeos no llegaron a África para educar a su gente, sino para saquear sus riquezas y empobrecer sus culturas. Camus denunció la falta de escuelas en 1939. En sus "Crónicas argelinas" podemos leer: "La sed de aprender del Kabile y su gusto para el estudio son legendarias. Es que el Kabile, además de sus disposiciones naturales y su inteligencia práctica, entendió rápido que la escuela puede ser un instrumento importante de emancipación... A este país le hacen falta escuelas... Hoy solamente una décima parte de los niños kabiles en edad de escolarización puede beneficiarse de esta enseñanza... Los kabiles reclaman pues escuelas, como reclaman pan" (Camus, 1984a: 919-923).*

La situación descrita por Camus en sus reportajes sobre la Kabilia reflejaba al resto de Argelia. Durante la colonización, la falta de escuelas era evidente. El historiador francés nacido en Argelia, Benjamin Stora, señala cifras comparativas antes y después de la independencia: "En 1961, los jóvenes franceses eran escolarizados en un 100 \%. Los niños argelinos a menos del $15 \%$. El número de los argelinos inscritos en la primaria llegaba apenas a 700000 [...] en 1980 a más de cuatro millones y medio. La entrada escolar de 1982 recibe [...] 80000 estudiantes en las universidades, eran solamente 2800 en 1963" (2004: 59).*

Durante las dos primeras décadas de la independencia, Argelia construyó miles de escuelas en cada rincón del país. Por falta de cuerpo docente, se invitó a cooperantes de países amigos. Más de trescientos mil cooperantes, en su mayoría franceses, pero también belgas, suizos y canadienses, vinieron a Argelia para contribuir con su desarrollo. Los de Medio Oriente llegaron para enseñar el árabe. De modo que en veinte años de independencia el número de maestros argelinos “pasa de 700 a 19 000” (Stora, 2004: 59).

Así, pues, los franceses, que fueron los colonizadores, regresaron en calidad de educadores. De manera que los lazos entre los pueblos francés y argelino no se limitan a ciento treinta y dos años de historia común, no se interrumpen en 1962, sino que continúan en diversas formas. Pocos argelinos vivían en Francia durante la colonización. En cambio, después de la independencia, la inmigración avanza a pasos gigantescos. De 471,020 inmigrantes argelinos en Francia en 1968 pasaron a 820,900 en 1988 (Stora, 2004: 53). Hoy día más de dos millones de argelinos viven en Francia (Mehenni, 2004: 
37). La presencia de cooperantes franceses en Argelia y de inmigrantes argelinos en Francia genera interpretaciones de todo tipo, incluso de carácter xenófobo. Hay quienes sólo ven el odio entre los dos países, cuando en verdad existe una complicidad y una pasión profunda entre ambos pueblos, cuya historia es como un divorcio mal hecho. Lo cierto es que este vaivén permanente permite el cruce de culturas. Quizás un día podamos decir, sin enrojecer, que decenas de miles de franceses han contribuido a la construcción de Argelia, y al otro lado del Mediterráneo, decenas de miles de argelinos han contribuido a la prosperidad de Francia. Hace falta una revisión de nuestra historia común para destacar lo bueno de nuestra experiencia conjunta. Si nosotros no asumimos nuestra historia, tal vez las generaciones futuras lo harán con sabiduría.

Durante las dos primeras décadas de independencia la enseñanza se hacía principalmente en francés. Las primeras decenas de miles de profesionales superiores, ingenieros y técnicos, formados después de la independencia, eran francófonos. Luego vino el proceso de la arabización. A partir de los años ochentas, como los arabófonos encontraban dificultades en el mercado laboral, algunos veían con envidia el éxito de sus conciudadanos francófonos.

En los años ochentas, grupúsculos de fanáticos religiosos, llamados "hermanos musulmanes" o "los barbudos", comenzaron a formarse. No recurrían a la violencia, aunque mantenían un discurso de odio contra lo que a sus ojos representaba los símbolos del Occidente: el vino, el cabaret, las formas de vestirse... obligaban a sus mujeres a ponerse el velo. Y como no podían hacer nada contra el Occidente, entonces acusaban a los francófonos de ser instrumentos del neocolonialismo, de perversos, simplemente por tomar una cerveza, y, para las mujeres, por vestirse elegantemente, negándose a tapar su belleza.

Durante un viaje a Argelia, hace dos años, un grupo de mujeres universitarias, cuya sed de libertad es insaciable, me dijo: "Jamais, jamais nous n'accepterons la culture $\mathrm{du}$ voile, et la soumission n'est la culture de personne, $\mathrm{c}^{\prime}$ est une simple imposition = nunca, nunca aceptaremos la cultura del velo, y la sumisión no es la cultura de nadie, sino una imposición...”

A pesar de esta ebullición, de 1962 a 1992 Argelia era uno de los países más tranquilos del mundo: no había violencia, ni inseguridad ciudadana, y la pobreza era muy escasa. Se encontraban carros de cooperantes y de nacionales a la orilla del mar, sin vigilancia, y nadie los tocaba. En las aldeas colgaban la ropa en el jardín toda la noche, nada de ladrones, las puertas permanecían sin llave. Los argelinos vivían con seguridad. Argelia avanzaba en el camino del desarrollo y del progreso, con dificultades sin duda, pero avanzaba. Los observadores nacionales y extranjeros admiraban "el milagro argelino" (Stora, 2004: 53). Los más optimistas pronosticaban: en unas dos décadas más, Argelia será el Japón del Mediterráneo.

¡Ay de nosotros y la paradoja del tiempo! El pasado se nos fue y el futuro es oscuro para cualquiera. Tal vez no hay más que el momento presente en el que recordamos el ayer con nostalgia e imaginamos el mañana con esperanza. Conviene recordar los versos de Victor Hugo (Rincé, 1986: 90): 
Que peu de temps suffit pour changer toutes choses

(Cuán poco tiempo basta para cambiar todas las cosas.)*

\section{La guerra civil de los años noventas}

A comienzos de la década de los noventas, la situación de Argelia era excepcional en África y en el Mundo Árabe. Se respiraba un aire de libertad, los partidos políticos se formaban, se crearon periódicos de tinte verdaderamente libre y crítico, comenzábamos a creer que la democracia no era sólo un sueño, sino que vivir democráticamente era posible. Varios argelinos en el exilio empezaron a volver a su tierra amada.

Cuando se creó el Frente Islámico de Salvación (FIS), muchos observadores se preguntaron: ¿por qué se autorizó un partido religioso que pregonaba abiertamente por la televisión su ideología radical, el odio a la diferencia, la discriminación de la mujer y el sueño de instaurar una República islámica?

Rachid Mimouni advirtió, en De la barbarie en general y del integrismo en particular, que esta ideología era peligrosa: "Sin embargo, cuando observamos los métodos de acción del FIS en Argelia, no podemos dejar de establecer paralelismos turbadores con los movimientos fascista italiano y nazi alemán [...] Estos movimientos se acercan en su voluntad deliberada de recurrir a la violencia" (1992: 153).*

Lo criticaron. Decían que exageraba. ¿Cuándo se ha tomado en cuenta el criterio del intelectual argelino? La historia le ha dado la razón.

En 1992, Argelia cae en la violencia. El sueño democrático se esfumó. Todo empezó a raíz de la anulación de la segunda vuelta de las elecciones legislativas del 26 de diciembre de 1991. El FIS ganó la primera ronda con 42,05 \% de los votos emitidos, es decir, $24,79 \%$ del total de los votantes inscritos, si se toma en cuenta el abstencionismo (Carlier, 1992). Los militares anularon el segundo turno. Los dirigentes del FIS fueron arrestados. Y el baño de sangre comenzó. Los fundamentalistas se consideraban lesionados. Les habían robado su victoria. Al no haber podido instaurar una República islámica mediante las urnas, algunos querían lograrlo con las armas y los métodos terroristas. ¿El resultado? Un drama humano difícil de curar. Según la versión oficial: "cerca de 150000 muertos, pero también, según las cifras oficiales, 200,000 huérfanos de guerra y un millón de niños traumatizados" (Ghorbal, 2003: 72-74).* Varias fuentes periodísticas coinciden en indicar más de 200,000 muertos hasta la fecha; las madres de los 14,000 desaparecidos piden justicia; "más de medio millón tomaron el camino del exilio" (Semian, 2005: 77), entre los cuales al menos 250,000 profesionales: intelectuales, artistas, médicos, periodistas y empresarios (Zirem, 2002). Pero treinta y dos millones de argelinos se quedaron y resistieron con dignidad y valentía.

En honor a la verdad, hay que aclarar que los terroristas no tenían la exclusividad del horror. El pueblo se encontraba entre dos fuegos, por un lado, los terroristas, por otro, los excesos de los militares. Varios observadores denuncian los abusos programados por algunos generales. El testimonio de Habib Souaidia, ex oficial de las fuerzas es- 


\section{$252 \square$ DIVERSIDAD CULTURAL Y LINGÜÍSTICA EN ARGELIA}

peciales, La guerra sucia, aporta pruebas fehacientes acerca de violaciones masivas a los derechos humanos imputadas a algunos generales (2001). Los islamistas recibían ayuda de Irán, sobre todo de Arabia Saudita, y particularmente de un tal Ben Laden, célebre hoy, desconocido en aquel entonces. En los años noventas, la prensa argelina lo señalaba como el proveedor financiero de los islamistas radicales y como uno de los terroristas más peligrosos del mundo. Estados Unidos no movió un dedo. "Washington no descartaba la eventualidad de una victoria de los islamistas" (Grandguillaume, 1997: 3).*Algunos observadores consideraban que Argelia iba a convertirse inevitablemente en una República islámica, lo que permitiría a Estados Unidos ocuparse del petróleo argelino, como lo hacían con sus amigos en Arabia Saudita.

Desde 1998 varios analistas señalan que el terrorismo islámico ya está vencido en Argelia, aunque todavía se reportan algunos atentados. Después del 11 de septiembre, los terroristas que operan en Argelia encuentran dificultades para recibir ayuda del extranjero. El Estado argelino sigue siendo laico, con una combinación del autoritarismo militar y de elecciones plurales y casi libres. Conviene concluir sobre el fanatismo religioso que ha causado mucho dolor en Argelia, recordando las palabras del poeta persa Omar Khayyam (1963: 47):

En los monasterios, las sinagogas y las mezquitas

Se refugian los débiles a quienes el Infierno asusta.

El hombre que conoce la grandeza de Dios

No siembra en su corazón la semilla del terror y la imploración.

\section{El himno a la resistencia pacifica, con dignidad y en todas las lenguas}

Durante los años terribles, como en las tragedias griegas, el drama argelino llama a la reflexión. Dice Amin Maalouf: "De Argelia suelen llegarnos las noticias más indignantes, pero también músicas innovadoras, difundidas por todos esos jóvenes que se expresan en árabe, en francés o en beréber; algunos se han quedado pese a todo en el país; otros se han ido, pero llevando consigo, dentro de sí, en ellos, la verdad de un pueblo, el alma de una cultura, y dando testimonio de ellas" (1999: 133).

En efecto, nunca la creación artística, literaria y cultural había sido tan floreciente y tan innovadora como en los años noventas.

Tahar Djaout, escritor y periodista, asesinado el 26 de mayo de 1993 (uno de los primeros de una larga lista de intelectuales víctimas de la barbarie), expresa la negación de su pueblo a callarse y su voluntad de seguir con la resistencia pacífica, mediante el siguiente poema (Memmi, 1994: 31):

Le silence, $c^{\prime}$ est la mort

Et toi, si tu parles tu meurs

$\mathrm{Si}$ tu te tais, tu meurs

Alors, dis et meurs.
El silencio es la muerte

Y tú, si hablas vas a morir

Si te callas, vas a morir

Entonces, habla antes de morir.* 
Cantantes arabófonos interpretaban músicas de sus conciudadanos amazighófonos. A modo de ejemplo se puede citar a Cheb Khaled, quien tradujo del kabile al árabe argelino la canción de Idir "Zwit arwit"; y Cheb Mami, quien hizo lo mismo con la canción "Zarartou” de Djamel Allam. Casi todos los grandes músicos tienen en su repertorio canciones en francés. Cabe decir dos palabras en honor de todas las víctimas: Fi Khater Cheb Hasni, quien cantaba el amor y que fue asesinado. El más conocido de los dramaturgos, Fellag, compone sus obras en tres lenguas. Es bien sabido que los artistas son las voces de los pueblos que ningún absurdo puede callar.

Algunos intelectuales de oficina desprecian la cultura popular en relación con el conocimiento académico; aunque Bajtín ha demostrado la importancia de la cultura popular (1970) en la vida de los pueblos. Algunos libros de historia ignoran el papel de la canción popular en Argelia. El poeta y cantante Ait Menguellet, considerado por Kateb Yacine como “el más gran poeta (argelino), porque está en el corazón del pueblo" (Yacine, 1989: 38), y el músico Idir fueron los primeros en criticar la desviación lingüística y cultural. De modo que la canción popular llega a ser el medio de lucha y de resistencia pacífica en defensa de la identidad plural.

El más rebelde fue el poeta y cantante Matoub Lounes, gran defensor de los derechos humanos, de las minorías, de la diversidad cultural y, particularmente, del derecho de su pueblo a existir con su diferencia. Comparable a García Lorca en España y a Víctor Jara en Chile, mataron a Matoub con "setenta y ocho balas" en condiciones oscuras el 25 de junio de 1998 (Zirem, 2002: 122). Pero desde su asesinato, es aún más popular. Su voz sigue inspirando a su pueblo (Slackman, 2005). ¡Setenta y ocho balas de gran calibre no han logrado callar al cantante popular! Muere el poeta, nace un mito: símbolo del Nif de Lhurma, o sea, la Dignidad y el Honor.

En Argelia el desliz viene del poder político. Con su humor característico, el periodista y escritor Sid Ahmed Samian, en su crónica: Le monde du TPI au TPS, es decir, El mundo del Tribunal Penal Internacional a la Televisión Por Satélite, sugiere la necesidad de llevar a algunos generales ante el Tribunal Penal Internacional (2005: 191-192).

Para persistir en sus abusos, el 17 de diciembre de 1996, el Consejo Nacional de Transición votó la "Ley sobre la generalización de la utilización de la lengua árabe" (Le Monde, 1988: 137). La cual especifica: "La utilización de toda lengua extranjera en las deliberaciones y debates de reuniones oficiales está prohibida" (Grandguillaume, 1997).* ¿Cuáles son las lenguas que la ley no menciona y que pretende prohibir? Obviamente no se trata del español o el náhuatl. Se trata del francés y del amazighe. Mas ambas lenguas se niegan a morir por decreto, siguen vivas en el alma del pueblo.

Algunos analistas se preguntaban si la ley sobre la arabización y la prohibición del francés y del amazighe no fue una provocación programada.

Cuentan una historia anecdótica, que revela el humor argelino y su capacidad de convertir su realidad en bromas: un ingeniero arabófono, desilusionado de la francofonía, se había refugiado en el Medio Oriente, muy lejos de Argelia, para vivir plenamente su arabismo. Al ver esta ley, regresa a Argelia. Encuentra una oferta de empleo en un periódico, y se presenta en la oficina de reclutamiento. Le dan un formulario en francés. 


\section{$254 \square$ DIVERSIDAD CULTURAL Y LINGÜÍSTICA EN ARGELIA}

Furioso, el ingeniero se rebela: “¿Cómo, ustedes no conocen la ley?” ¿Cuál ley?” Le responde el jefe de la oficina. "La ley sobre la generalización de la lengua árabe", precisa el ingeniero. "Oiga, insiste el jefe de reclutamiento, si usted quiere el trabajo, llene el formulario, si no váyase a otra parte, aquí trabajamos, no hacemos política".

Esta broma revela el lugar del francés en Argelia. En efecto, es la lengua de trabajo. Casi todas las reuniones oficiales en los ministerios y en las empresas se llevan a cabo en francés.

Esta ley y otros abusos del gobierno central provocaron una marcha de más de dos millones de personas de la Kabilia a Argel, el 14 de junio del 2001 (Zirem, 2002). Los manifestantes reclamaron a viva voz: "Corrijan la historia, no somos árabes" (Le Matin, 2001). Hay que ser sordo, ciego y loco para no ver un grave problema de identidad en Argelia.

En algunas regiones hay quienes se niegan abiertamente a hablar árabe. Se ha creado un Movimiento para la Autonomía de la Kabilia (MAK) (Mehenni, 2004), y el Arch, entre otras organizaciones, exigiendo el reconocimiento de su lengua materna, como lengua nacional y oficial. En defensa de su idioma, su identidad y su cultura, esta región está en resistencia permanente.

Del lado oficial, desde su regreso al poder en 1999, el presidente Abdelaziz Bouteflika viola sistemáticamente la ley de arabización. En la televisión habla en árabe y en francés, en la Asamblea Nacional, en París, pronunció su discurso en francés. En las regiones amazighófonas, al no conocer la lengua de sus antepasados, comienza sus discursos con los saludos habituales en amazighe: "Azul felawen". En la campaña del 2009 para buscar la reelección presidencial por tercera vez, declaró: "Je suis un authentique amazighe = Soy un auténtico amazighe" (AFP, 2009).

A principios de este siglo, el presidente formó una comisión de alto nivel para la reforma de la escuela. Los expertos señalan que uno de los problemas fundamentales de la educación es un fallo lingüístico.

Desde 2003, la reforma de la escuela comienza. El ministerio de educación reclutó más de veinte mil profesores francófonos, entre los cuales hay miles de jubilados, para reafrancesar gradualmente la escuela pública. En cuanto a las escuelas privadas, la enseñanza se efectúa en francés. El amazighe está reconocido constitucionalmente como lengua nacional. Su enseñanza se garantiza en las escuelas primarias, en los colegios y en las universidades.

\section{La exclusión empobrece, la integración cultural enriquece}

De las consideraciones anteriores se vislumbran varias conclusiones:

Argelia ha sido desde sus orígenes la tierra del encuentro de civilizaciones distintas. Aunque los encuentros no han sido pacíicos, sino caracterizados por las guerras y todo tipo de violencia, han posibilitado el contacto con el Otro, el enriquecimiento mutuo y el forjamiento de una cultura plural de la que podemos estar orgullosos. 
La comprensión del drama argelino no se logra con el estudio del fenómeno religioso. Amin Maalouf dijo con acierto: "Podemos leer diez voluminosos tomos sobre la historia del Islam desde sus orígenes y seguiremos sin entender en absoluto lo que está sucediendo en Argelia. Pero si leemos treinta páginas sobre la colonización y la descolonización, lo entenderemos mucho mejor" (1999: 81).

En efecto, la tragedia argelina se explica con el análisis profundo de dos momentos históricos de los últimos cincuenta años. El pueblo argelino lleva dos heridas en el corazón: la guerra de liberación, 1954-1962, y la guerra civil de los años noventas, más fresca aún. Estas dos heridas han causado trastornos humanos, morales, culturales, políticos y, sobre todo, ideológicos. No hay que buscar los problemas de Argelia en otro lado.

Desde Aristóteles hasta Rousseau los filósofos políticos insisten en que el fin o objetivo del Estado es la búsqueda del bien común y de la seguridad de sus ciudadanos. Observamos con dolor en el alma que cinco décadas después de la independencia no se ha logrado construir un Estado de derecho y de prosperidad, en el que reinen la seguridad y la paz, de tal manera que cada argelina y argelino pueda sentirse protegido como en el regazo de una madre afectuosa.

Es bien sabido que la autocrítica nos hace crecer, aunque a menudo cuesta admitir la crítica. Resulta un espectáculo triste y bochornoso en un país tan rico como Argelia, que haya de entre siete a nueve millones de personas en situación de pobreza, casi un tercio de la población. La desesperación es tal que miles de jóvenes fuertes y bellos arriesgan sus vidas en barquitos en búsqueda de una vida mejor al otro lado del Mediterráneo.

El tema de las lenguas es un absceso agudo que agita la cuestión de la identidad. La promulgación de una ley que protege a una lengua, excluyendo a las otras, no es la solución. Los defensores de la lengua y de la religión únicas temen la diversidad, creen que su visión uniforme garantizaría la unidad nacional. Cuando en verdad, la exclusión de algunos componentes de la identidad del pueblo podría causar la división. Lo ideal sería promover y proteger las tres lenguas que hablan diariamente los argelinos: el árabe, el amazighe y el francés.

La situación de Argelia no es una excepción, existen países políglotas que viven en armonía. El caso de Canadá, desde casi siempre, es ejemplar en materia de la diversidad cultural, y en España, desde la transición democrática en 1975, se respetan las especificidades lingüísticas regionales con el sistema de las comunidades autónomas. Suiza es el ejemplo más admirable en materia de integración lingüística y cultural.

La pregunta es: ¿pueden los argelinos vivir en armonía con sus diferencias? Sí podemos $=$ Nekni nezmar $=$ Hna neqadru $=$ Nous le pouvons $=$ Yes we can.

Bajo el colonialismo se intentó afrancesarnos y eliminar los componentes que llevamos en las venas. Después de la independencia se ha intentado arabizarnos y borrar nuestras herencias amazighe y francófonas. Lo cierto es que el colonialismo forma parte del pasado, mas la lengua francesa es nuestra, es una puerta hacia la modernidad; es un componente de nuestra cultura, de nuestra identidad plural. Pese a todos los golpes, el pueblo argelino resiste con dignidad y se niega a dejar de ser lo que es. La identidad individual o colectiva, ¿qué es? No es aquella que soñamos, no es 
la que se intenta imponer desde arriba, es la que tenemos. Somos lo que somos o no somos nada. La identidad, en efecto, soy yo ante al espejo. Basta con aceptarse. Voilà tout. Eso es todo.

Es preciso promover el intercambio cultural entre los países africanos y los latinoamericanos para conocernos mejor $\mathrm{y}$ aprovechar nuestras experiencias. Y esto podemos y debemos hacerlo desde ahora. De México podemos aprender su aceptación del mestizaje cultural, y construir la Plaza de las Tres Culturas en Argel, nuestro lugar común en honor a nuestra identidad de esencia plural. En efecto, somos orgullosamente un pueblo amazighe, árabe y francófono. Hemos sabido absorber lo bueno de los pueblos hermanos nacidos como nosotros del Mediterráneo; pero también nuestra tierra ha sido la cuna de grandes espíritus que han contribuido generosamente a la comprensión de la condición humana. No sólo el colonizador influye en el colonizado, hemos enriquecido la famosa cocina francesa con nuestra cultura culinaria, el cuscús inventado por nuestras abuelas resulta ser un plato nacional en Francia. Pese a su trato injusto con nosotros, debemos mucho a la patria de los derechos humanos, no hay duda, Francia nos ha impregnado con su cultura.

Algunos sólo quieren ver una imagen estigmatizada del mundo musulmán. Y de nuestra música, ¡qué!, ¡nuestras artes y letras!, y nuestros poetas que cantan el amor y la libertad, los temas universales que habitan el corazón de cada ser humano. Resulta ofensivo que algunos medios de comunicación de Occidente sólo se refieren al mundo musulmán para mostrar el fanatismo religioso, como si los intelectuales laicos que sufren el integrismo y lo denuncian no existieran. Conviene recordar las palabras de Juan Goytisolo: "Los occidentales parecen olvidar que su historia y pasado reciente no les faculta para dar lecciones a nadie: a quienes denigran sistemáticamente al Islam, habría que recordarles que en el ámbito de éste no ha habido nunca Inquisiciones sangrientas como la nuestra ni genocidios de poblaciones enteras como las de los indoamericanos ni exterminios colectivos a lo Hitler ni empleo de Armas mortíferas como la de Hiroshima" (1997: 20).

La cultura de la violencia fundamentalista es una realidad, aunque merece un análisis político y no religioso, es un peligro eminente en Argelia, pero también amenaza a la humanidad. Lo ocurrido el 11 de septiembre pone en evidencia que estos radicales, decididos a sacrificarse para ganarse las llaves del paraíso celestial, son capaces de dañar y de golpear incluso a la primera potencia mundial. Pero la solución no es la invasión de pueblos inocentes, que sufren las dictaduras y el yugo del fanatismo.

Algunos dicen que El choque de civilizaciones (Huntington, 1996) es inevitable, opinan sin razón que los valores de libertad, de tolerancia y de laicidad son un privilegio de Occidente, y que la democracia sería incompatible con el Islam... Los mismos profetas del futuro advierten "que los inmigrantes mexicanos acabarán con el sueño americano" (La Nación, 2004). W're tired of this kind of narrow-minded ideas! ¡De verdad! Estamos cansados de estas visiones estrechas del mundo, que fomentan el odio, cuya interpretación sería un pecado contra la humanidad a tenor del pensamiento de José Martí. En sus palabras: "El hombre no tiene ningún derecho especial porque 
pertenezca a una raza u otra: dígase hombre, y ya se dicen todos los derechos [...] Todo lo que divide a los hombres, todo lo que los especifica, aparta o acorrala, es un pecado contra la humanidad" (1995: 128-131).

En efecto, si leemos a los pensadores del Siglo de las Luces y de otras épocas se vislumbra otra verdad. ¿A quién se dirige Rousseau cuando proclama: "El hombre ha nacido libre y en todas partes se encuentra encadenado?" (1943: 58).* ¿Y Montesquieu que insiste sobre los fundamentos del Estado de derecho en El espíritu de las leyes, y la importancia de la mirada del otro en las Cartas persas?... ¿Y Platón que propone una República ideal fundada sobre la educación y la justicia?... Un análisis reflexivo de estas ideas permite decir, sin equívoco, que desde siempre los libres pensadores de todos los países se dirigen al género humano. De lo que se trata es del devenir de la humanidad.

¿Cuál es la alternativa? Ante la xenofobia, la discriminación y los fanatismos religiosos, políticos y de toda índole, podemos y debemos alzar la voz: pensamos que otras visiones de mundo son posibles. Los muros ideológicos y de concreto, tales como el de la frontera entre México y Estados Unidos y el que divide en zigzag a los palestinos y a los israelíes, entre otras barreras que se construyen para dividir a los pueblos, algún día serán destruidos como el antiguo muro de Berlín. Cabe recordar al cantante mexicano Carlos Santana y su canción compuesta por el músico argelino Rachid Taha (CD, 1999):

\title{
Es hora de reconocer que todos somos una voz Abraza el concepto venimos de la misma voz Me necesitas tú a mí más y más que yo a ti.
}

\author{
People people let's start together \\ Let's do it right \\ People people let's love one another \\ I know we know how
}

Existen los senderos de la paz: la tolerancia, el diálogo fructífero, la ética laica, la promoción de la cultura de los derechos humanos, simplemente el respeto por la diferencia, la apertura hacia el otro, en vez de tenernos miedo unos a otros, semejantes a los lobos de que habla Hobbes.

Urge un nuevo Contrato Social entre los pueblos. En síntesis, para lograr la convivencia pacifica con nuestras diferencias, y para la seguridad de todos: cada uno de nosotros, si quiere que su cultura sea respetada, debe comenzar por respetar la cultura de los demás. Y como decía Sócrates: aquel que quiere cambiar el mundo ha de empezar por cambiarse a sí mismo.

La diversidad cultural significa la promoción de todas las actividades culturales que buscan la belleza, el bienestar y la perfección de los habitantes de la aldea global. Y si nos permitimos parafrasear a Antígona (Sófocles, 2001), diríamos: no hemos nacido para odiar, sino para amar.

La alternativa es la reconciliación y el diálogo entre las culturas. 


\section{Obras citadas}

AFP. 2009. "Présidentielle en Algérie: Bouteflika tend la main aux Kabyles". París: www.algerie-focus.com/2009/03/28.

AzEM, Slimane. 1980. "Tamurt-iw azizen”. París: Production la Voix du Globe.

BAKHTINE, Mikhaïl. 1970. L'oeuvre de François Rabelais et la culture populaire au Moyen Âge et sous la Renaissance. París: Gallimard.

BELlO, Andrés. 1945. Gramática de la lengua castellana. Buenos Aires: Sopena.

BYRAM, Michael. 1997. Culture et éducation en langue étrangère. París: Éditions du Seuil.

CAMus, Albert. 1984a. Chroniques algériennes (Actuelles III). Oeuvres complètes. Essais. París: Pléiade. 1984b. Noces à Tipasa. Oeuvres complètes. Essais. París: Pléiade.

CARLIER, Omar. 1992. "De l'islamisme à l' islamisme: la thérapie político-religieuse du FIS”. Cahiers d'Études Africaines, vol. XXXII (2), núm. 126. Pp. 185-219. París: Éditions de l'École des hautes études en sciences sociales.

CEMBERo, Ignacio. 2005. "Plan Marshal autóctono en Argelia: el país invertirá 55000 millones de dólares". El País, 31 de julio de 2005. Madrid.

Cervantes, Miguel de. 2000. Don Quijote de la Mancha. Madrid: Edición Jorge A. Mestas.

Cubertafond, Bernard. 1999. L'Algérie contemporaine. París: Que sais-je. PUF.

ESTEFANÍA, Rafael. 2005. "El país de los hombres azules, recorrido por el desierto de los tuareg, al sur de Argelia". El País, 30 de abril de 2005. Madrid.

FREUD, Sigmund. 1970. El malestar en la cultura. Madrid: Alianza Editorial.

FuENTES, Carlos. 1992. El espejo enterrado. México: FCE.

. 1991. “La langue espagnole, ma patrie”. Magazine littéraire, núm. 287. París. Pp. 104-109.

García Calleja, José y Javier GonzÁlez Martín. 2005. Cervantes y su época. Madrid: Edimat Libros.

Ghorbal, Samy. 2003. "Les enfants de la haine”. Jeune Afrique, núm. 2206. París. Pp. 72-74.

Goytisolo, Juan. 1997. De la Ceca a la Meca. Madrid: Alfaguara.

GRANDGUILLAUME, Gilbert. 1997. “Arabisation et démagogie en Algérie”. Le Monde diplomatique, febrero. París.

Huntington, Samuel P. 1996. The clash of cilvilizations and the remaking of world order. Nueva York: Simon Schuster.

Julien, Charles-André. 1994. Histoire de l'Afrique du Nord, des origines à 1830. París: Payot \& Rivage.

KHAYYAM, Omar. 1963. Robáiyát. Barcelona: Zeus.

LACOSTE, Yves. 1985. El nacimiento del tercer mundo: Ibn Jaldún. Barcelona: Península.

La Nación. 2004. San José. 17 de abril de 2004. 
Le Matin. 2001. www.lematin.dz. Argel: junio.

Le Monde. 1988. Lettres d'Algérie. París: Folio-Actuel, núm. 60.

MAALOUF, Amin. 1999. Identidades asesinas. Madrid: Alianza Editorial.

MAMMERI, Mouloud. 1987. Entretien avec Tahar Djaout. Argel: Lapohmic. 1983. "Tazwart”. Askuti de Said Sadi. París: Imadyazen.

MaOUGALl, Mohamed Lakhdar. 2004. Kateb Yacine: l'indomptable démocrate. Argel: Apic.

Marraou, Henri. 1965. Saint Augustin et l'augustinisme. París: Éditions du Seuil.

MARTí, José. 1995. Ensayos y crónicas. Madrid: Anaya / Mario Muchnik.

MeHENNI, Ferhat. 2004. Algérie: la question kabyle. París: Michalon.

Memmi, Albert. 1994. "La folie intégriste”. Magazine Littéraire, núm. 323. París. P. 31.

Mimounit, Rachid. 1992. De la barbarie en général et de l'intégrisme en particulier. París: Press-Pocket, núm. 2521.

OUARDANE, Omar. 1990. La question berbère dans le mouvement national algérien 1926-1980. Québec: Septentrion.

RINCÉ, Dominique y Bernard Lecherbonnier. 1986. Littérature, textes et documents, XIXe siècle. París: Nathan.

Rousseau, Jean-Jacques. 1943. Du Contrat Social. París: Aubier Monteigne.

SAnTANA, Carlos. 1999. "Migra”. CD. Supernatural. Composición Rachid TAHA, Carlos SANTANA y T. LINDAYS. Madrid: Arista Records.

SEMIAN, Sid Ahmed. 2005. Au refuge des balles perdues, chroniques des deux Algérie. París: Éditions La Découverte.

SLACKMAN, Michael. 2005. "Voz de cantante berébere asesinado todavía inspira a su pueblo: Lounes Matoub”. The New York Times / La Nación, 19 de noviembre de 2005. San José.

SóFOCLES. 2001. Tragedias completas. Madrid: José Vara Donado.

SoUAÏDIA, Habib. 2001. La sale guerre. París: Folio-Actuel, núm. 88.

STORA, Benjamin. 2004. Histoire de l'Algérie depuis l'indépendance 1. 1962-1988. París: Éditions La Découverte.

UNESCO. 2001. Declaración Universal sobre la Diversidad Cultural. París.

YACINE, Tassadit. 2001. "Tant que le pouvoir attisera la haine". (Forma parte del reportaje: Kabyles, le peuple indompté). Le Nouvel Observateur, 10-16 de mayo. París. Pp. 34-41.

1992. "Entretien avec Kateb Yacine: aux origines des cultures du peuple”. (Edición especial: homenaje a Kateb Yacine). Awal, núm. 9. París: Editions Maison des Sciences de l'Homme.

1989a. (Recopiladora). Tradition et Modernité dans les sociétés berebères. París: Awal.

1989b. “Quand meurent les étoiles”. Libération, 3 de octubre de 1989. París.

ZIREM, Youcef. 2002. Algérie: la guerre des ombres, les non-dits d'une tragédie. Bruselas: GRIP / Complexe. 